とこそ技術者の目標であり，技術革新の目標であると思う。それにはまず，少年持代か ら，技術江親しめる器境と，技術全般通ずる理論の確立が必要となる。

第 3 席 2
小沢 久 之 西
(名城大学)

\title{
論交要 旨
}

技術革新沁ずるためには, 工学系大学卒業者の一般教育利目, 専門利目の中, 特江工 学之関係の梁いものに対して実力の向上を計らねばならぬ。その向上はどうして行うこと

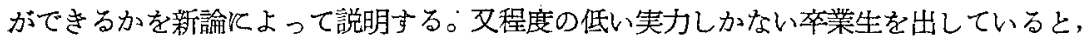

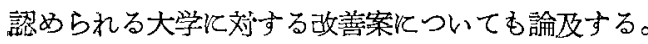

専門科目の教官斯界の最高権威者であることが最も望ましいが，多数の権威者を得る ことの困難さと，経費節約を考虑して地域別教育の力法を提唱する。

最高権威者の待遇, 社会的地位, 海外との連絡, 研究費等についても若干の説明を加兄 て工業教育者のあり方を論ずる。

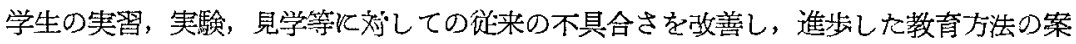
を採用するよう推笑するものである。

\section{1. 序論}

原子力の利用, 諸作業のオートメーション化, 誘導弾, 人工偉星, 高速航空機, テレビ レーダーと数兑上げれば，数限りない多数の新しい科学文化が，如何に多数の優秀な技術 者を迎えいれようとしているか梳，衆知の事実である。今年 3 月飞工学部系の大学を卒業

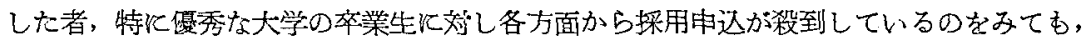
業界の激しい活貤状洗がよく分るではなか?

この時期に, 新しく新制大学の工学部を卒業した人達路, 果して社会の要望に応した古 派な人として学密を栄立ったであるうか？又今直ちに充分役に立つということは困難に 
照 賞 論 交

してす，近い将来役泣ちうる素質を備えて，巣立って行ったであるうか？

数ある新制大学の中には, 害力の甚だ疑わしい学生を出している大学がないとは云えな

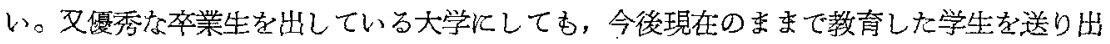
していて息いものであろうかと大いに疑間を感ずるあのである。

相当数多くの新制大学から, 実力の低い卒業生を現状のま东で壮しているのであったな ら仗，社会恃大学卒業生の奏力に広範な差のあることを知らず，拯用して後化余りにも実

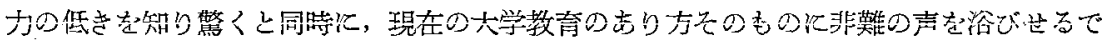
あろう。これは大学卒業生全体の社会的信用を失う原因ともなるのでまことに重大な問題 である。実際程度の低い卒業生に䴔し試験を行ってみたら，これが工学士かとあきれざる を得ない卒策生が存在することは遗戌ながら事実である。こんな状態を何時まですつづけ ていてよろいいのか？いけないととは当然であるので，てれの㸚策として国家試験によ

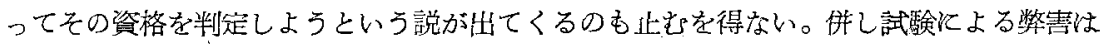
幾多の人が認めている処てはありこれ䇃する対策が国家試験の外化無いなどとは考克

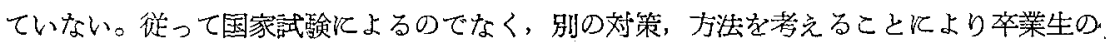
素質を向上したい上願うむのである。

\section{2. 教育方法の检討}

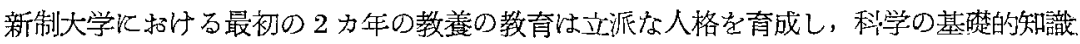
を修得させようとしているが，求門教育を教え込むてとがないので，専門教育からは余り に毛过遠と思われる科目について教育が行われている。欲ってその是非については多くの， 論議が行われつつあるので，本論と大い関係はあるが，とこではこの問題にふれること なく、この教育万法を是認して論議をすすめることにしたい。

一般教育科目の教育のあり方は，大学教育後半の専門科目教育を充份高度なあのとする. ことが，可能であるような方向江向ける必要がある。すなわち高度な專門教育を充分うけ うるような資格者をつくり出すという点汇重点が招かれなくてはならない。

説明をしやすくするため化，先ず大学教育後半の専門利目教育の教育方法を検討し，改 革的意見を述べようとするものである。

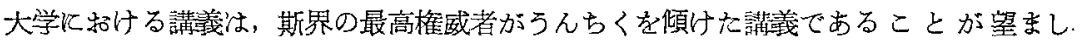
w。

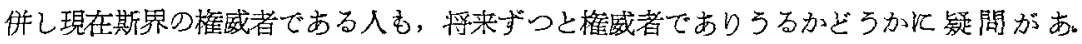


る。

大学に抽る教官の待遇, 社会がその教官に执う尊敬の念, 社会が教官に俈与する便宣 の程度ということ等を合せ考えると甚だ疑わしく感じる。年龄的们漸次衰えるみせること む起りうるが，これは暫く論外とするも何時までもその教官が最商権威者であるために は，諸種の施策がなされればならない。これには文部省としてむ多額の費用をとれに投ず ることを覚悟しなけ狄な゙ならい。從って多数の権威者を維持してゆく方策は立らうへくく あない。

徉ってての效策はごく少数の人ト限定せざるを得なくなるであろう。

今日の如く多数ある新制大学《斯界の権威者を波れなく配置しうる程，国として能力が あるとは到底考えられないし，又との配置をするように要求するのむ余りにむ常軌を逸し た無理な注文である。

\section{3. 地 域 别 教 育}

如何に立派な権威者が東京で請䉝をしているからといって，九州とか北海道から講義を きくために上京する等のことは考完られない。

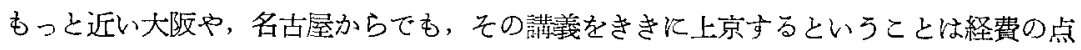
と時間の点から棓さるベくもない。

併し東京のある大学で権威者から立派な偝军が行われているならは，学生の立場からす れば, 東京の他の大学の学生むその諢羙をきくこが出来るならば, 何も自分の大学の二

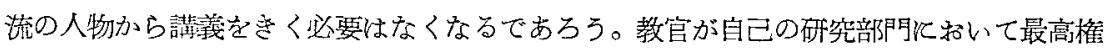
威として謨義をもつならぼ，他の大学からもとの講義をききにくることであろう。

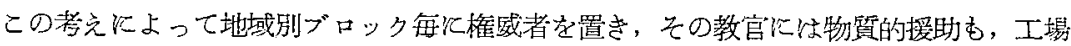

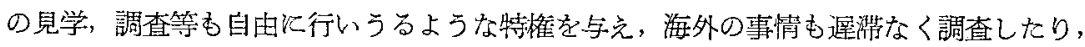
学術会議にも頻繁に参加できるような立埸に括くことによって，益ふ権威者としての地位 を持続せしめるようなオ法を考えたいものである。

\section{4. 学生能力の質的向上}

橎威者が秩序的に偍秀な請義をしても，それをきく学生の程度が低い埸合や，熱心でな かったり，雑音をたてたりする屯のであったりした埸合には，立派な教育を行うことはで 
繁 賞 論 交

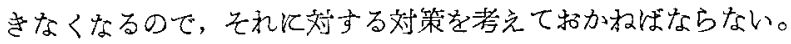

程度の低い学生を請義渗加せしめないだけの責任は各大学で負わねばならないし，講： 義する人は学生の不熱心なもの, 能力のないものに䇏しては簡単に聴講を禁此しうるよう

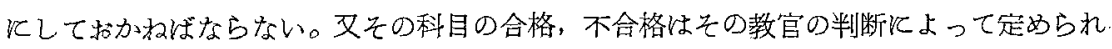
ればよいので，大学てよる差等は全然考虑さる必要がないようにしておきたい。能力 の低、学生を出している大学注この専門教育の関閇で弱点を暴露し，何時も卒業不能とな

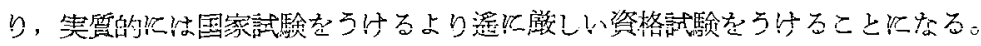

\section{5. 一般教育科目の教育方針}

この急劇を発生させない上うにするためには，一般教育利目の教育方針索如何にするか. を検討しな暗ればならない。

先ず工学部の一般教育利目について調べてみると下の 5 蒝列がある。

1. 人交科学采列

3. 自然科学系列

5. 体

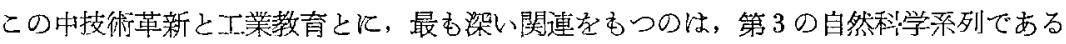
ことはいうまでもない。とれ故本系列の授業内容をどの程度のものにして，専門青を行 うのに菠障なく教育することができるかを，各大学が協議し，ある線までを必要と定めた ならげその線までの教育をどんな程度の低い学生をむつ大学も行うだけの責任をとる ようにしなければならない。この線までの教育をうけてない学生は今後の專門育の履修 が不能になるし，大学の卒業が不可能になるので，卒業生の素質は飛躍的改善される。

専門科目の教官は自然利学系列つ教育程度を充分飞認識し, 專門科目の满義つ特, 不必 要な講義を重複して、しないように充分の注意を配る必要がある。非常て能率的, 効果的; な潸義であるととが望恋しい。

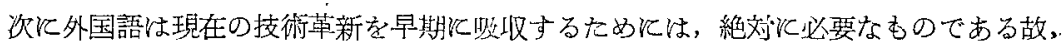
少くとむ外国交献を自由読みうる程度浡教育することを必要条件としたい。

\section{6. 専門科目の教育方針}

共通專阿利目として孝えられるすの 
1. 基 礎 数 学

2. 工 業 数 学

3. 工 業 物 理

4. 図

学

5.工 業 経 営

等があるが，この中の数学，物理等は今後の専門科目の教育程度が相当高くなることを 考慮し, 協議によって必要最小限度の線をうち出し, この線を絶剠沉きらないように奏施。 しなくてはならない。

今機械工学科の例をとって專門兴目の検討をしてみる。

工業力学材料力学 機棈学 熱力学

水力学 機械要素般設詰製 図

上記の科目は純専門科目の基楚をなす科目とみることができるので，これる協議の上教 育すべき標潗を決定して，ての標準までを各大学で裁传任をもって教えるようにすれ。 ばこれらの利目については他の大学の講義をきくために埸所を変えたり，時間を浪費し， たりする必要がない科目と考光ることができる。

最む新しい現在の知識を教える必要のある専門科目としては

航 空 機

自動車

誘 導 紭

蒸汽原䉂機

内燃機関

水力機械

鉄道車輛

化学機械

纎維機械

空気機械

撸気暖房冷凍

工業材料

機械工作

その外，今後加わると思われる原子力関係，オートメーション閔係の專門科目教育を遅 㴖なく追加したいものである。

今日の尌門科目の特間配置そみて警くことは，甚だ古いもの例えば蒸汽機関等の講義が 多数の時間をしめていることである。これは長特間教える必要があるというよりは，密る これらのことに精通していた古い人がまだ大学に残っているために多数の時間をとってい ると思われる。

それに反し，新しい科目の教育はどこもその必要を痛感しているが，教官をうることが できないために教えられないといった方か適当である。従って現在のままで行ったら程度 の覀い大学化属する学生は，これら新しい專閒科目の修得が不可能になるかも知れない。 これは結局大学に対する社会の信用を失㳫することとなるので, 各大学共通の聴檴てきる, 謂義を設けることは社会にも貢献することとなる。

專門科目の実習については，所定の試験に合格した者に対してのみ実習を行わせること にしたい。奏習にも大学の差別を設けることなく, 大きい国家的見地から実施して欲し 


繁 賞 論 交

w。

政府はこうした族策沉効してはドンドン盼成金を支出するようにして欲しい。

これらの専門科目担当の教官の知譏が後退することがないように，たえず海外の事情に

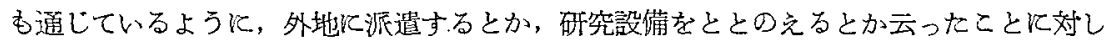
施策する必要がある。前記提唱の力法を実施すれば独来のように事を分散的に行うのでな く集中的に行いうるようになる。

\section{7. 審查機関}

各大学枋いて，自己の大学怯どの科泪に重点置くかの力針を決定して，新しく提唱 したいと思う新設の資格審查機関に，その理由，内容等を䛨細代説明し，その积目の教育 を担当するという資格の与えられることる討請しなければならない。資格番查機関は冭分

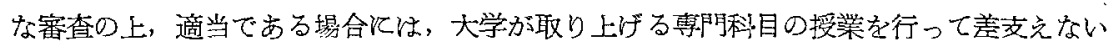

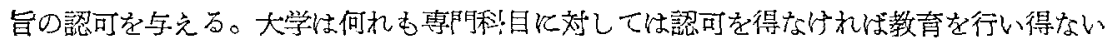
こととする。

新しい見地に这った認可制にすれば，国家の経費が重複して使用されることも減少し， 経費を相当節減することができる。このようにしてできた誁義, 実験, 夷習を私大の学生も きいたり，行ったりすることができるならは，国家の援助の恩惠に浴することともなり， 同時江真に技術的に有能な人材を社会に送り出すことが可能になる。

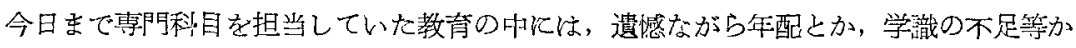
ら本論治いて説明した專門利目担当の教官としては不適当な人達が出てくる。こうした 人達の中には恐らく自分自身，専門稿目教育の莎重に堪えられないでいる人達も多数ある と思う。それ故これらの人はできるだけ一般教育科目の教育をしていたたくこととした W。

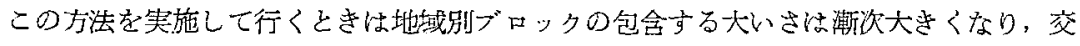
通譏関の発達は優秀な人物のむとに学生を集合せしむるとととなり, 自ら程度の高い優秀 な学生を社会溇ることとなるであるう。

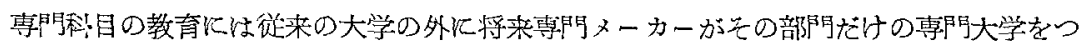
くるに到るであるう。例壳ば航空機製作会社はこの関係の黄門利目大学をつくるである 亏。

併しこれもここに述べた教育方法の一少用にすぎはいこうした大学ができても同一の 
運用により何等支障はない。

\section{8. 教宝に枕ける教育方法の改善}

フートを使用するか，教科雪を使用するかは，その教官の希望せられる処でいいと思う が，大团なととは，スライドを使用したり，映画を使用したりして，できるだけ広範国に わたった知識を短時間の中㳊育するようと努めてゆきたい。

スシイドを使用するようなるのは，できるだけプッントにして学生汇配布するような方 法をとっていただきたい。暗室中のスライド講義屾その場で見たり，きいたりするには結 構であるが，腤くてノートするととむ，見難い場合炕見直すというととむできないからで ある。

構造を示す模型とか，標本の類はできるだけ多数集めて，学生が自由に利用できる方途 を講したい。

\section{9. 学生のエ場実習}

工場の立場からすれば，方々の大学から見学，実習希望せられ学生の程度む上，下ま ちまちでただ見さ党す礼ばよろしいという学生から，非常熱心理解し，学びとりたい と努力する学生もある。こえな風では受けいれ側の工場としては義務を果し，社会的批判 あうけずと無事にすめばそれでよるしいという態度にならざるを得ない。

これは垁習，見学を依頼する方の体制が悪いのであって，今後専門別学生の色分けむ ハッキリしてくれば，教官の方む充艻の統制をとりうるし，文部省側でも各ブロック間の

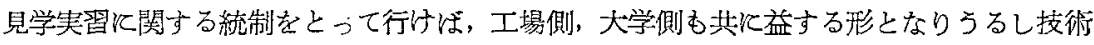
向上飞も非常飞役立つことと思う。

\section{0. 教官と工場, 研究所との関係}

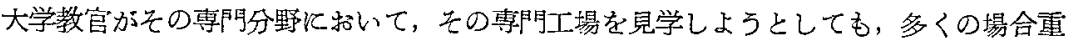
.要工場飞招いて許可をうることが難しい。

これは工場が大学教官に秘密な処を見せたくないとと，他の業者に秘密が洩れはしない かと拓それる等が理由である。換言すれば業者が大学教官をそれ程人格的に尊重してない 
㢡 賞 論 交

ことを意味し，又一面大学教官に見せても等に見せるだけと考劣ていることに基因してい る。業者は教官に接することにより失う观はあるけれどあ，得る処はないとの見艘から大

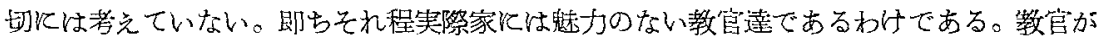

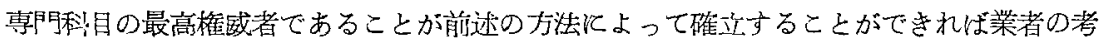
えすを一変せしむることができると思う。

即ら人格の䯩いその道の最高権威者である教官を工場に招いて得る処がなければ，その

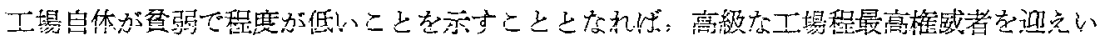

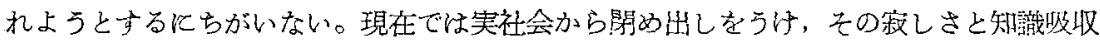
の不能借えか䄈て，手近な工場と関係を結び僅に接触を保つ。これは他の工場索調查し たり，見学したりしたいと思う時俳常な邪槐となる。大学教官は一段高い処から，工場 に接しうるような地位に方つべきで，余り特定な工場と関俰を結ぶことは好ましいことで 社学り

大学教官は研究機関からも閉め出乙をくう場合がある。この理由は工墕の場合と大同小

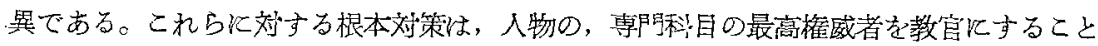

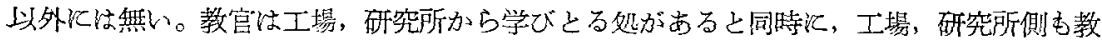
官から得る処のあるようにする必要がある。社会政策的には，教官に見てもらったり，そ の意見安とりいれておかなければ，将来発展しようとしても，をのチャンスに恵まれない といったような方法を考勴するのも一方泆であると思う。何れにしても，真に立源な人を その位置に秥くことが前惿条件である。

\section{1. 教官の外地派遣}

現在で大学の格式によってその派遗が伡されたり，不請可になったりしているように 思われる。古い大学, 学生数の多い大学, 社会的化有名な大学, そこには站派な学者もい

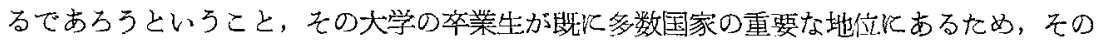
大学の教官を海外に派遣して和けば割合無事であると考えられることには，一忘もっとも な理由はあるが，今後は最高権威者を外地出すという方針汇重きを置き，大学の名にこ

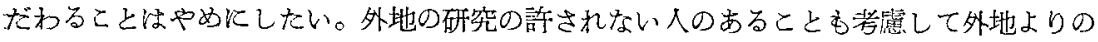
䜌朝者はその報告会を州国後直ちに行い，従来の報告会のように見物談のようなものでな く, 專門的な点についての誁しい報告会であって欲しい。 
12. む す び

上述の簡算な説明では意をつくしていないしとが実に多数あるが，幸にして共鳴者をう ることができるならば，技術革新に刘しての工業教育のあり方についての数多くのデイス カッションの機会を得たいものである。

\section{第 3 席 3}

石名四喜 久 雄

（鐘淵紡績株式会社防府工埸）

前 言

第 1 章 技術革新要素の一, 二

1. 目的の明示と徹底

2. 誰が為の生産か

第 2 章 技術革新の一考察と方法論

1. 果して先天的炕不可能?

2. 先ず子供の玩具から

3. 学童用鉛筆

4. 技術の標淮化

5. 技術と政治

第 3 章 工業教育の在り力

1. 語学偏重主義から脱却

2. 実物教育飞主力を注ぐ事

3. 利学化関する学間炕力を注ぐ事

4. 独立自尊の修慈

5. 原料，材料の吟味を習慣とする事

6. 品質管理の手法を教うる事

7. 国立綜合技術研究所の設立

結 諭 